\title{
UJI AKTIVITAS GEL EKSTRAK ETANOL BUAH OKRA (Abelmoschus esculentus) TERHADAP PENYEMBUHAN LUKA BAKAR DERAJAT II KULIT PUNGGUNG KELINCI JANTAN GALUR NEW ZEALAND
}

\author{
Arrum Fadlillah Abdurrahman, Ika Puspitaningrum, Wulan Kartika Sari* \\ Sekolah Tinggi Ilmu Farmasi Yayasan Pharmasi Semarang \\ Jalan Letnan Jendral Sarwo Edie Wibowo Km.1 Plamongansari Semarang \\ *E-mail: wulankartika06@gmail.com
}

\begin{abstract}
Abstrak
Luka bakar (burn) merupakan cedera akibat paparan dengan sumber panas seperti listrik, zat kimia, atau radiasi. Tanaman yang terdapat senyawa fitokimia dengan aktivitasnya dalam penyembuhan luka bakar salah satunya adalah buah okra (Abelmoschus esculentus). Tujuan dari penelitian ini untuk mengetahui aktivitas penyembuhan luka bakar derajat II, dan konsentrasi efektif gel ekstrak etanol buah okra pada kulit punggung kelinci jantan galur New Zealand. Penelitian menggunakan 6 ekor kelinci jantan galur New Zealand, berumur 4 sampai 5 bulan dan berat badannya 2 sampai 3 kg. Masing-masing kelinci diberikan 5 kelompok perlakuan. Kelompok perlakuan F1, F2 dan F3 diolesi gel ekstrak etanol buah okra 5\%, 10\%, dan 20\%, kelompok F4 diolesi basis gel karbopol 940 dan kelompok F5 diolesi gel Bioplacenton $^{\circledR}$. Setiap hari diamati secara makroskopis hingga diameter luka tertutup sempurna $(d=0)$. Pengujian statistika menunjukkan adanya perbedaan signifikan antara $K(-)$ dengan ketiga konsentrasi gel ekstrak etanol buah okra dalam pengujian $\mathrm{pH}$, daya lekat, daya sebar dan viskositas, disimpulkan bahwa konsentrasi ekstrak etanol buah okra berpengaruh terhadap karakteristik gel. Gambaran makroskopis setelah pemberian gel ekstrak etanol buah okra F2 dan F3 menunjukkan adanya perbedaan tidak signifikan dibandingkan dengan $K(+)$, menunjukkan bahwa konsentrasi $10 \%$ dan $20 \%$ merupakan konsentrasi efektif penyembuhan luka bakar.
\end{abstract}

Kata kunci: buah okra (Abelmoschus esculentus), diameter luka, gel, luka bakar

\section{PENDAHULUAN}

Luka bakar atau dapat juga disebut sebagai burn merupakan cedera akibat dari kontak secara langsung atau paparan sumber panas seperti listrik, zat kimia, atau radiasi (Rahayuningsih, 2012). Luka bakar dapat terjadi pada kulit, saluran cerna, saluran pernapasan, dan selaput lendir. Akibat yang timbul karena luka bakar yaitu terjadinya peningkatan dan kerusakan permeabilitas pada pembuluh kapiler, kerusakan pada jaringan kulit, bahkan dalam keadaan parah menyebabkan gangguan yang serius pada ginjal, paru-paru dan hati (Moenadjat, 2009). Luka bakar dapat menimbulkan kerusakan terutama pada kulit. Bagi manusia kulit sangat penting perannya dalam penyeimbangan kadar air serta elektrolit dan juga berfungsi sebagai barrier yang melindungi dari lingkungan luar termasuk mikroorganisme. Apabila terjadi kerusakan pada kulit sangat penting dilakukan pengembalian integritas kulit sesegera mungkin.

Di Indonesia sendiri banyak masyarakat yang menggunakan obat-obatan bahan alam sebagai alternatif untuk penyembuhan luka terbuka. Salah satu tanaman yang memiliki kandungan fitokimia dengan aktivitasnya untuk penyembuhan luka bakar adalah buah okra (Abelmoschus esculentus). Di dalam buah okra (Abelmoschus esculentus) positif terdapat kandungan flavonoid dan tanin yang berperan dalam penyembuhan luka (Nurfatwa, 2018), serta terdapat saponin yang memiliki peranan dalam penyembuhan luka bakar (Mandey, 2013). Penelitian sebelumnya menyatakan bahwa pemberian ekstrak buah okra dengan konsentrasi sebesar $10 \%$ memiliki aktivitas secara signifikan dalam penyembuhan luka dilihat dari pengurangan luas permukaan luka dan peningkatan daya tarik kulit dalam proses penutupan luka pada kulit (Farooqui dkk., 2018). Pada penelitian ini buah okra diaplikasikan dalam bentuk sediaan gel luka bakar. Keuntungan dari sediaan gel adalah kenyamanan dalam pemakaian dan memiliki kemampuan penyerapan ke dalam kulit yang baik, memberikan sensasi rasa dingin, tidak lengket dan mudah dicuci dengan menggunakan air (Rismana dkk., 2013).

Dalam penelitian ini bahan yang digunakan adalah karbopol 940 sebagai gelling agent dalam formula sediaan gel. Stabilitas sediaan gel dengan gelling agent karbopol memiliki stabilitas yang 
baik pada konsentrasi 2\% (Megawati dkk., 2019). Gel dengan basis karbopol 940 dipilih karena sifat dari metabolit sekunder (flavonoid, alkaloid, saponin, tanin) yang polar, sehingga akan lebih mudah lepas dari basis karbopol yang juga bersifat polar atau hidrofilik (Arissandi, 2009). Berdasarkan uraian diatas, penelitian dilakukan untuk mengetahui aktivitas gel ekstrak buah okra terhadap penyembuhan luka bakar pada kulit punggung kelinci jantan galur New Zealand yang diinduksi dengan lempeng besi panas dengan diameter $2 \mathrm{~cm}$, kemudian dilihat penyembuhannya secara makroskopis yaitu dengan mengukur diameter pengecilan luka bakar pada kulit punggung kelici jantan galur New Zealand yang sudah diberikan perlakuan.

\section{METODE PENELITIAN}

\section{Bahan dan Alat yang Digunakan}

Buah okra yang digunakan merupakan buah okra yang diperoleh dari perkebunan di Kota Kendal, Jawa Tengah kemudian dilakukan determinasi tanaman di Laboratorium Sekolah Tinggi Ilmu Farmasi Yayasan Pharmasi Semarang. Bahan lain digunakan adalah kelinci jantan galur New Zealand, etanol 70\%, gel Bioplacenton ${ }^{\circledR}$ (Placenta bovine-neomisin sulfat), etil klorida, akuades, karbopol 940, TEA (Trietanolamin), gliserin, metilparaben.

Alat-alat yang digunakan yaitu alat-alat gelas, cawan porselen, kain flanel, sudip, batang pengaduk, anak timbangan, lumpang dan alu, waterbath, lampu ultraviolet (UV) 254, timbangan digital, rak tabung, penggaris, jangka sorong "Vernier Calipter" 150x0.02 mm/6"x1/1000, termometer, pH meter "Hanna HI 2210-02", viskometer Brookfield DV-1 Prime, rotary evaporator "Heidolph", kain kasa, plester, solder, lempeng besi bundar diameter $2 \mathrm{~cm}$, alat uji daya lekat, alat uji daya sebar.

\section{Pembuatan Gel Ekstrak Etanol Buah Okra (Abelmoschus esculentus)}

Ekstrak etanol buah okra diperoleh dengan cara remaserasi 300 gram serbuk simplisia dengan 1,5 liter etanol $70 \%$ selama 3 x 24 jam. Maserat dikumpulkan dan dikentalkan menggunakan rotary vaccum evaporator (Ismail, 2018). Pembuatan gel ekstrak etanol buah okra dilakukan dengan cara mengembangkan karbopol 940 sebagai basis gel menggunakan akuades panas hingga mengembang, ditambahkan metil paraben, gliserin dan TEA (Trietanolamin) diaduk hingga terbentuk massa gel yang jernih dan homogen. Kedalam basis gel yang sudah dibuat ditambahkan ekstrak etanol buah okra diaduk homogen hingga membentuk massa gel buah okra yang berwarna hijau muda.

Tabel 1. Formula Gel Ekstrak Etanol Buah Okra

\begin{tabular}{ccccc}
\hline Bahan & F1 & F2 & F3 & F4 \\
\hline Ekstrak buah okra (\%) & 5 & 10 & 20 & - \\
Karbopol 940 (\%) & 2 & 2 & 2 & 2 \\
Gliserin (\%) & 10 & 10 & 10 & 10 \\
TEA (\%) & 2 & 2 & 2 & 2 \\
Metil paraben (\%) & 0,2 & 0,2 & 0,2 & 0,2 \\
Akuades hingga (\%) & 100 & 100 & 100 & 100 \\
\hline
\end{tabular}

\section{Uji Farmakologi}

Penelitian ini telah mendapatkan ijin dari Komite Etik Penelitian Kesehatan dengan Ethical Approval no 072/CN-SW/KEPK/STIFAR/EC/I/2020. Hewan uji yang digunakan yakni kelinci jantan galur New Zealand yang berumur 4 sampai 6 bulan dengan berat badan 2 sampai $3 \mathrm{~kg}$. Bulu kelinci pada bagian punggung dicukur menjadi 5 area luka bakar dengan ukuran $3 \times 3 \mathrm{~cm}$ dan jarak antar perlakuan $\pm 2 \mathrm{~cm}$ (Wardani, 2015).Induksi panas dilakukan 1 hari setelah proses pencukuran Sebelum dilakukan penginduksian dengan elemen besi panas berdiameter $2 \mathrm{~cm}$ pada suhu $70^{\circ} \mathrm{C}$ selama 5 detik, kulit punggung kelinci jantan yang sudah dicukur dan dibersihkan diberikan pemaparan anestesi lokal menggunakan etil klorida spray. Selanjutnya, 5 area luka bakar ini diberikan gel dengan pembagian kelompok yaitu F1 gel ekstak etanol buah Okra konsentrasi 5\%, F2 gel ekstrak etanol buah Okra konsentrasi 10\%, F3 gel ekstrak etanol buah Okra konsentrasi 20\%, F4 basis gel Karbopol 940 (kontrol negatif), F5 gel Bioplacenton (kontrol positif). 
Pengamatan luka bakar dilakukan setiap hari hingga $(\mathrm{d}=0)$ atau luka telah tertutup oleh jaringan baru.

\section{Analisis Data}

Data yang diperoleh berupa karakteristik fisik gel dan total diameter luka bakar selama 14 hari yang kemudian dianalisis secara statistika parametrik one-way ANAVA dengan taraf kepercayaan 95\% menggunaan IBM SPSS (Statistical Product and Service Solutions) statistics 26.

\section{HASIL DAN PEMBAHASAN}

\section{Uji Skrining Fitokimia Ekstrak Etanol Buah Okra (Abelmoschus esculentus)}

Uji skrining fitokimia pada ekstrak etanol buah okra yang dilakukan meliputi uji pendahuluan dan dilanjutkan dengan uji penegasan Kromatografi Lapis Tipis (KLT). Senyawa yang diuji dalam ekstrak etanol buah okra yaitu alkaloid, flavonoid, saponin tanin dan steroid/terpenoid. Uji skrining fitokimia menunjukkan bahwa ekstrak etanol buah okra mengandung senyawa alkaloid, flavonoid, tanin dan saponin.

Tabel 2. Skrining Fitokimia Ekstrak Etanol Buah Okra

\begin{tabular}{|c|c|c|c|}
\hline Senyawa & Pereaksi & Hasil & Keterangan \\
\hline \multirow[t]{3}{*}{ Alkaloid } & $\begin{array}{c}\mathrm{HCl} 2 \mathrm{~N} \\
\text { saring }+ \text { Dragendorff }\end{array}$ & Kuning & (+) alkaloid \\
\hline & $\mathrm{HCl} 2 \mathrm{~N}$, saring+Mayer & Endapan putih & (+) alkaloid \\
\hline & $\begin{array}{c}\mathrm{HCl} 2 \mathrm{~N} \\
\text { saring+Bourchardat }\end{array}$ & $\begin{array}{c}\text { Endapan coklat } \\
\text { kehitaman }\end{array}$ & (+) alkaloid \\
\hline Flavonoid & $\begin{array}{c}\text { Serbuk } \mathrm{Mg}+\mathrm{HCl}+\mathrm{Amil} \\
\text { Alkohol }\end{array}$ & Larutan merah & (+) flavonoid \\
\hline Saponin & $\begin{array}{c}\text { Air panas, kocok }+\mathrm{HCl} \\
2 \mathrm{~N}\end{array}$ & $\begin{array}{l}\text { Busa konstan } 3 \mathrm{~cm} \\
\text { selama } 10 \text { menit }\end{array}$ & (+) saponin \\
\hline Tanin & $\mathrm{FeCl}_{3}$ & Hijau kehitaman & $(+) \operatorname{tanin}$ \\
\hline $\begin{array}{l}\text { Steroid } \\
\text { /terpenoid }\end{array}$ & $\begin{array}{c}\text { Asam asetat } \\
\text { anhidrat+H2S04 }\end{array}$ & Coklat & (-) steroid / terpenoid \\
\hline
\end{tabular}

Hasil pengujian skrining fitokimia yang telah diperoleh dilanjutkan dengan uji penegasan berupa uji Kromatografi Lapis Tipis (KLT). Menurut hasil pengujian KLT yang telah dilakukan, KLT menunjukkan adanya senyawa alkaloid, flavonoid, saponin, dan tanin. Adanya senyawa dalam ekstrak etanol buah okra ditandai dengan hasil positif pada uji penegasan ekstrak etanol buah okra.

Tabel 3. Pengujian KLT Ekstrak Etanol Buah Okra

\begin{tabular}{|c|c|c|c|}
\hline Senyawa & Eluen & Rf dan Noda Sampel & Keterangan \\
\hline Alkaloid & $\begin{array}{c}\text { Etil Asetat:Metanol:Air } \\
(100: 13,5: 10)\end{array}$ & 0,81 (Jingga) & (+) Alkaloid \\
\hline Flavonoid & $\begin{array}{c}\text { N Butanol:Asam } \\
\text { Asetat Glasial:Air } \\
(4: 1: 5)\end{array}$ & 0,19 (Coklat) & (+) Flavonoid \\
\hline Saponin & $\begin{array}{c}\text { Kloroform:Metanol:Air } \\
(64: 50: 10)\end{array}$ & 0,81 (Kuning coklat) & (+) Saponin \\
\hline Tanin & Methanol:Air (6:4) & 0,56 (Hijau) & (+) Tanin \\
\hline Steroid & $\begin{array}{c}\text { N Heksan:Etil Asetat } \\
(4: 6)\end{array}$ & 0,18 (Hijau) & (-) Steroid \\
\hline
\end{tabular}

\section{Uji Karakteristik Gel Ekstrak Etanol Buah Okra}

Ekstrak etanol buah okra yang digunakan pada penelitian ini berupa sediaan gel topical dikarenakan sediaan berupa gel topikal memiliki keuntungan diantaranya adalah, nyaman untuk dipakai, tidak lengket, mudah meresap ke dalam kulit, memberikan sensasi rasa dingin di kulit, serta mudah dibersihkan dengan air (Rismana dkk., 2013) Kualitas sediaan gel ditentukan dengan dilakukannya pengujian karakteristik fisik sediaan yang meliputi uji organoleptik (bau, bentuk dan warna), homogenitas, $\mathrm{pH}$, viskositas, daya lekat dan daya sebar dengan hasil sebagai berikut : 
Tabel 4. Hasil Uji Karakteristik Gel Ekstrak Etanol Buah Okra

\begin{tabular}{cccc}
\hline Pengujian & $\mathbf{5 \%}$ & $\mathbf{1 0 \%}$ & $\mathbf{2 0 \%}$ \\
\hline Organoleptik & & & \\
Bentuk & Kental+++ & Kental++ & Kental+ \\
Bau & Khas buah Okra & Khas buah Okra & Khas buah Okra \\
Warna & Hijau muda & Hijau tua & Hijau tua pekat \\
Homogenitas & Homogen & Homogen & Homogen \\
pH & $5,38 \pm 0,084^{\mathrm{a}}$ & $5,14 \pm 0,089^{\mathrm{a}}$ & $4,8 \pm 0,112^{\mathrm{a}}$ \\
Daya lekat (detik) & $0,982 \pm 0,008^{\mathrm{a}}$ & $0,946 \pm 0,011^{\mathrm{a}}$ & $0,912 \pm 0,013^{\mathrm{a}}$ \\
Daya sebar (cm) & $3,934 \pm 0,047^{\mathrm{a}}$ & $4,280 \pm 0,045^{\mathrm{a}}$ & $4,660 \pm 0,042^{\mathrm{a}}$ \\
Viskositas (cPs) & $2137 \pm 2,449^{\mathrm{a}}$ & $2035,4 \pm 2,074^{\mathrm{a}}$ & $1551,8 \pm 3,564^{\mathrm{a}}$ \\
\hline
\end{tabular}

Keterangan :

,,$++++++\quad=$ semakin kental

a $\quad=$ menunjukkan berbeda signifikan $(\mathrm{P}<0,05)$ dengan pengujian antar konsentrasi gel

Hasil pengujian organoleptis yakni bentuk, bau, warna dan homogenitas dilakukan dengan cara visual. Uji organoleptik bentuk sediaan ketiga formula berupa gel dengan tingkat kekentalan yang berbeda, pada bau sediaan ketiga sediaan memiliki bau yang sama yaitu bau khas dari ekstrak etanol buah okra. Warna sediaan pada formula F3 memiliki warna yang lebih pekat dibandingkan dari formula F1 dan F2 karena pada formula F3 konsentrasi ekstrak etanol buah okra lebih banyak sehingga menghasilkan warna yang lebih pekat. Pengujian homogenitas menunjukan bahwa semua gel homogen terlihat dengan tidak adanya butiran kasar yang terdapat dalam sediaan gel

Penurunan $\mathrm{pH}$ terjadi karena $\mathrm{pH}$ basis memiliki $\mathrm{pH}$ yang lebih basa $(\mathrm{pH}=5,8)$ daripada $\mathrm{pH}$ ekstrak etanol buah okra yang memiliki $\mathrm{pH}$ lebih asam $(\mathrm{pH}=4,6)$, sehingga pada formula yang memiliki konsentrasi ekstrak etanol buah okra lebih besar maka $\mathrm{pH}$ sediaan akan semakin menurun, dan viskositas sediaan gel juga menurun. Viskositas gel yang menurun menyebabkan turunnya daya lekat. Namun, berbanding terbalik dengan daya sebar, semakin menurunnya viskositas maka diameter daya sebar akan semakin besar. Viskositas sediaan semakin menurun pada gel dengan konsentrasi ekstrak etanol buah okra yang lebih tinggi, disebabkan oleh pengaruh $\mathrm{pH}$ dari ekstrak yang memiliki sifat asam ditambahkan ke dalam basis sediaan yang mengandung karbopol yang pada suasana asam konsistensi sediaan akan berubah menjadi lebih encer dan viskositasnya akan menjadi lebih rendah karena karbopol hanya dapat membentuk masa dengan konsistensi yang kental pada suasana basa atau dalam kondisi alkalis. Nilai $\mathrm{pH}$ yang semakin rendah berpengaruh terhadap aktivitas sediaan gel ekstrak etanol buah okra karena apabila luka mengalami kontaminasi mikroba, semakin asam nilai $\mathrm{pH}$ maka sediaan memiliki aktivitas antibakteri yang dapat mematikan bakteri dengan mekanismenya yaitu menyebabkan ketidakseimbangan $\mathrm{pH}$ internal sel dan $\mathrm{pH}$ eksternal sel sehingga ion $\mathrm{H}+$ dari luar berdifusi ke dalam sel dan terjadi lisis sel bakteri, kemudian enzim, molekul serta protein terdenaturasi berakibat kematian sel bakteri (Wigati dkk., 2019).

\section{Uji Farmakologi}

Konsentrasi gel ekstrak etanol buah okra yang semakin tinggi dapat meningkatan waktu penyembuhan luka bakar. Pada gambar 1, menunjukkan bahwa F3 yaitu gel ekstrak etanol buah okra dengan konsentrasi 20\% menyembuhkan luka bakar lebih cepat daripada konsentrasi yang lainnya dengan pembanding F4 atau basis gel karbopol 940 yang cenderung lebih lama.

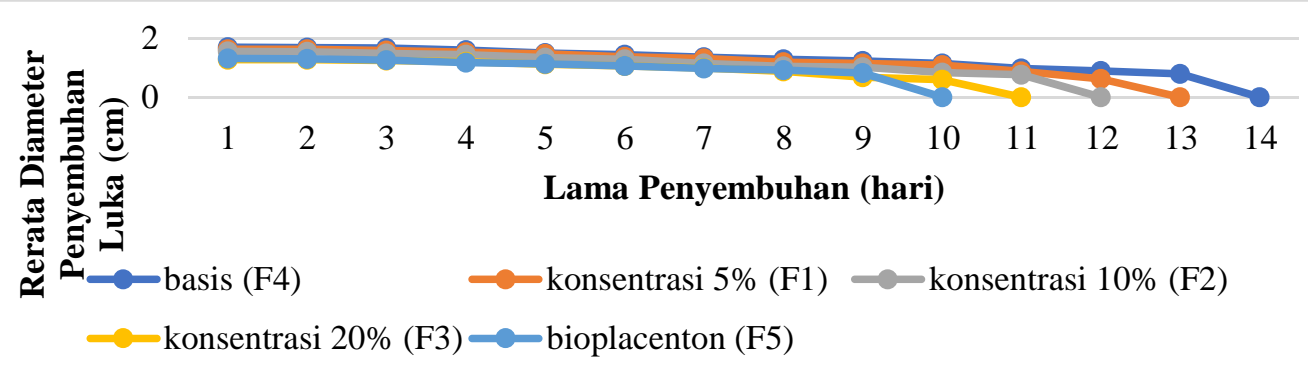

Gambar 1. Kurva Hubungan Rerata Diameter Penyembuhan Luka dan Lama Penyembuhan 


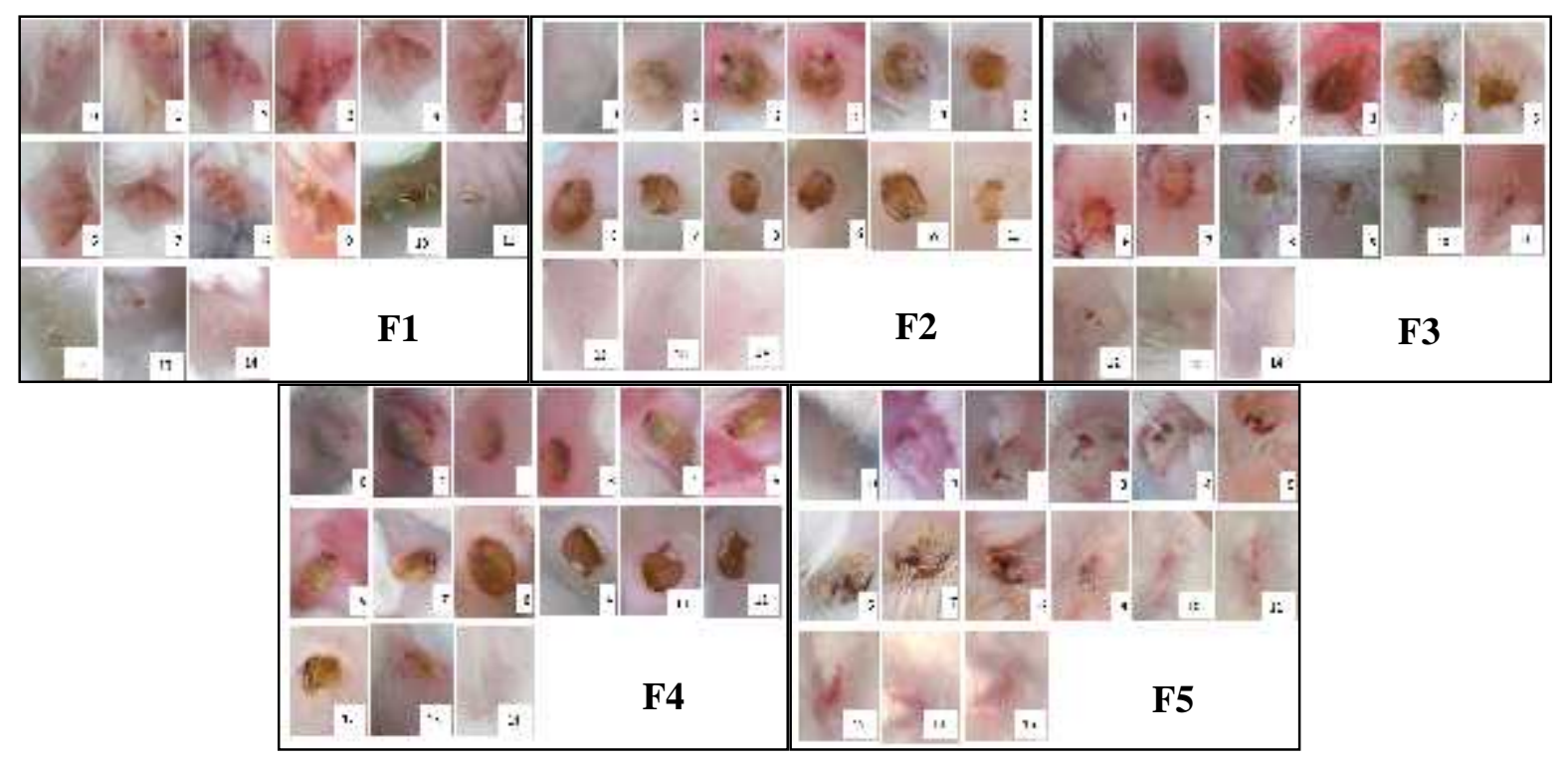

\section{Gambar 2. Pengamatan Makroskopis Penyembuhan Luka Bakar pada Kulit Punggung Kelinci Jantan Galur New Zealand}

Terdapat 3 fase dalam penyembuhan luka bakar untuk menggantikan jaringan yang rusak. Pertama yaitu fase inflamasi, pada fase ini terputusnya pembuluh darah pada luka menimbulkan terjadinya pendarahan lalu penghentian pembuluh darah oleh tubuh dilakukan dengan vasokonstriksi, yaitu pengerutan pada ujung pembuluh darah yang terputus (Ulviani dkk., 2016). Dapat dilihat pada gambar 2, pada hari ke-3 masing-masing formula menunjukkan kondisi kulit yang sedang berada pada fase inflamasi dan belum membentuk scab (keropeng). Fase kedua adalah fase proliferasi, ditunjukkan dengan kondisi kulit hari ke-7 pada F1, F2, F3, K(-) dan $\mathrm{K}(+)$ yang dimana luka dipenuhi oleh sel radang, fibroplasia dan kolagen. Fase proliferasi akan membentuk jaringan yang memiliki warna kemerahan dengan benjolan halus yang biasa disebut dengan granulasi atau mulai terjadi pembentukan keropeng. Fase akhir dari proses penyembuhan luka yaitu fase maturasi yang dimana terjadinya penyerapan kembali jaringan yang berlebih dan membentuk kembali jaringan yang telah rusak (Ulviani dkk., 2016). Kondisi luka hari ke-10 pada F1, F3, dan $\mathrm{K}(+)$ telah mengalami fase maturasi, yaitu telah terjadinya pengelupasan keropeng yang terbentuk pada luka, mulai tumbuh bulu-bulu halus disekitar luka, dan warna kulit pada area luka berubah.

Gel ekstrak etanol buah okra dapat menyembuhkan luka bakar karena mengandung senyawa saponin, tanin, flavonoid dan alkaloid. Kandungan saponin untuk mempercepat pembentukan kolagen, yaitu struktur protein yang memiliki peran dalam penyembuhan luka dan mampu menurunkan fibrosis pada luka sehingga mencegah terbentuknya luka baru (Septiningsih, 2008). Kandungan tanin berfungsi sebagai astringen yang dapat mengecilkan pori-pori kulit, memperkeras jaringan kulit, menghentikan terjadinya penanahan (eksudat) dan pendarahan ringan sehingga dapat menutupi luka dan mencegah pendarahan ringan yang biasa timbul pada luka (Li dkk., 2011). Kandungan flavonoid merupakan golongan fenol yang memiliki aktivitas antiseptik, berperan memperbaiki kerusakan pada pembuluh darah, astringen, dan antioksidan yang memiliki berperan dalam peningkatan kecepatan dari proses epitelisasi (Nayak dkk., 2009; Saroja dkk., 2012). Kandungan alkaloid dapat berperan sebagai antimikroba, yaitu dengan mekanisme menghalangi komponen penyusun peptidoglikan sel bakteri (Priamsari and Yuniawati, 2019).

Hasil uji statistik menunjukkan bahwa data homogen dan berdistribusi normal ( $p>0,05)$, sehinga dilanjutkan dengan uji parametrik ANOVA satu jalan. Hasil uji ANOVA menunjukkan bahwa ada perbedaan antar kelompok $(p<0,05)$, kemudian dilanjutkan dengan uji Post Hoc untuk megetahui ada atau tidaknya perbedaan antar kelompok satu dengan yang lainnya. Hasil uji Post Hoc gel ekstrak etanol buah okra dengan konsentrasi 10\% (F2) dan 20\% (F3) memiliki perbedaan yang tidak signifikan jika dibandingkan dengan kelompok kontrol positif (F5) dengan nilai signifikasi $(p>0,05)$ hal ini menunjukkan bahwa gel ekstrak etanol buah okra dengan konsentrasi 
$10 \%$ dan $20 \%$ memiliki aktivitas dalam penyembuhan luka bakar karena kecepatan penyembuhan luka gel ekstrak etanol buah okra sebanding dengan kontrol positif. Diameter penyembuhan luka gel ektrak etanol buah okra pada hari ke 10 menunjukkan bahwa kontrol positif memiliki diameter $0,826 \mathrm{~cm}$ sedangkan F1 $1,095 \mathrm{~cm}, \mathrm{~F} 20,843 \mathrm{~cm}$ dan F3 0,595 cm. Namun, karena konsentasi efektif yang dimaksud adalah konsentrasi yang memiliki aktivitas yang sebanding dengan kontrol positif dan hasil penelitian ini mendapatkan 2 konsentrasi dengan aktivitas sebanding dengan kontrol positif yang ditunjukkan pada analisis data SPSS, maka konsentrasi efektif yang diambil adalah konsentrasi terkecil yang memiliki aktivitas untuk menyembuhkan luka bakar yaitu gel ekstrak etanol buah okra konsentrasi $10 \%$ (F2).

\section{KESIMPULAN}

Sediaan gel ekstrak etanol buah okra (Abelmoschus esculentus) memiliki aktivitas terhadap penyembuhan luka bakar derajat II pada kulit punggung kelinci jantan galur New Zealand, yang ditandai dengan mengecilnya diameter luka bakar. Gel ekstrak etanol buah okra (Abelmoschus esculentus) dengan konsentrasi $10 \%$ adalah konsentrasi efektif dalam penyembuhan luka bakar derajat II pada kulit punggung kelinci jantan galur New Zealand.

\section{SARAN}

1. Perlu dilakukan optimasi konsentrasi sediaan gel ekstrak buah okra untuk mendapatkan formula yang paling optimal yang dapat menyembuhkan luka bakar.

2. Perlu dilakukan penelitian lebih lanjut terhadap pengamatan makroskopis secara histologi pada kulit.

3. Perlu dilakukan penelitian farmakologi lebih lanjut tentang keefektifan gel ekstrak etanol buah okra $10 \%$ dan $20 \%$ untuk menemukan formula yang paling optimal dalam menyembuhkan luka bakar.

\section{DAFTAR PUSTAKA}

Arissandi, D. N. S. 2009. Pengaruh Basis Gel Poloxamer dan Karbopol terhadap Penyembuhan Luka Bakar Gel Ekstrak Etanol Umbi Wortel (Daucus carota L.) pada Kulit Punggung Kelinci. Skripsi. Surakarta: Universitas Muhammadiyah Surakarta.

Farooqui, M. B., Khasim, S. M., Rafiq, M., dan Khan, A. A. 2018. Evaluation of Wound Healing Activity of Abelmoschus Esculentus (Linn) in Albino Wistar Rats, European Journal of Pharmaceutical and Medical Research. 5(5). pp. 508-511.

Ismail, R. 2018. Pengaruh ekstrak buah okra (Abelmoschus esculentus) pada Mencit Putih Jantan Penderita Diabetes Melitus setelah Diinduksi Aloksan dan Uji Histopatologi. Skripsi. Padang: Universitas Andalas.

Li, K., Diao, Y., Zhang, H., Wang, S., Zhang, Z., Yu, B., Huang, S., dan Yang, H. 2011. Tannin extracts from immature fruits of Terminalia chebula Fructus Retz. promote cutaneous wound healing in rats. BMC complementary and alternative medicine. 11. p. 86.

Mandey, J. S. 2013. Analisis Botani dan Pemanfaatan Antimikroba Daun Gedi (Abelmoschus manihot (L.) Medik) sebagai Kandidat Bahan Pakan Ayam Pedaging. Hibah Doktor. Manado: Universitas Sam Ratulangi.

Megawati, Roosevelt, A., dan Akhir, L. O. 2019. Formulasi dan Uji Stabilitas Fisik Sediaan Gel Ekstrak Kulit Buah Rambutan (Nephelium lappaceum L.) sebagai Obat Sariawan Menggunakan Variasi Konsentrasi Basis Carbopol. Jurnal Farmasi Sandi Karsa. 5 (1). pp. $5-10$.

Moenadjat, Y. 2009. Luka Bakar: Masalah dan Tatalaksana Edisi ke-4. Jakarta: Balai Penerbit FKUI.

Nayak, B. S., Sandford, S., dan Maxwell, A. 2009. Evaluation of the wound-healing activity of ethanolic extract of Morinda citrifolia L. leaf. Evidence-based Complementary and Alternative Medicine. 6 (3). pp. 351-356.

Nurfatwa, M. 2018. Uji Toksisitas Akut Ekstrak Buah Okra (Abelmoschus esculatus L. Moench) terhadap Parameter Kadar Sgot dan Sgpt serta Histopatologi Hepar Tikus Galur Wistar. Journal of Pharmacopolium. 1 (2). pp. 88-93.

Priamsari, M. R. dan Yuniawati, N. A. 2019. Skrining Fitokimia dan Aktivitas Penyembuhan Luka 
Bakar Ekstrak Etanolik Morinda citrifolia L. pada Kulit Kelinci (Oryctolagus cuniculus). Journal of Pharmacy. 8 (1). pp. 22-28.

Rahayuningsih, T. 2012. Penatalaksanaan Luka Bakar (Combustio). Jurnal Profesi. 8 (Februari September 2012). pp. 1-13.

Rismana, E. Rosidah, I., Prasetyawan, Bunga, O., dan Erna. 2013. Efektivitas Khasiat Pengobatan Luka Bakar Sediaan Gel Mengandung Fraksi Ekstrak Pegagan Berdasarkan Analisis Hidroksiprolin dan Histopatologi pada Kulit Kelinci. Buletin Penelitian Kesehatan. 41 (1). pp. 45-60.

Saroja, M., Santhi, R., dan Annapoorani, S. 2012. Wound Healing Activity of Flavonoid Fraction of Cynodon Dactylon in Swiss Albino Mice. International Research Journal of Pharmacy. 3 (2). pp. 230-231.

Septiningsih, E. 2008. Efek Penyembuhan Luka Bakar Ekstrak Etanol 70 \% Daun Pepaya (Carica papaya L.) dalam Sediaan Gel pada Kulit Punggung Kulit Punggung Kelinci New Zealand. Skripsi. Surakarta: Universitas Muhammadiyah Surakarta.

Ulviani, F., Yusriadi, dan Khaerati, K. 2016. Pengaruh Gel Ekstrak Daun Sirih Merah (Piper crocatum Ruiz \& Pav) terhadap Penyembuhan Luka Bakar pada Kelinci (Oryctolagus cuniculus). Journal of Pharmacy. 2 (2). pp. 103-110.

Wardani, L. R. 2015. Aktivitas Gel Kolagen Sisik Ikan Kakap Merah (Lutjanus argentimaculatus) Terhadap Fase Epitelisasi pada Proses Penyembuhan Luka Bakar Kulit Kelinci "Gambaran Makroskopis Dan Mikroskopis". Skripsi. Semarang: Sekolah Tinggi Ilmu Farmasi Yayasan Pharmasi.

Wigati, D., Sari, W. K., dan Kristantri, R. S. 2019. Uji Aktivitas Antibakteri Yoghurt Susu Sapi Dan UHT terhadap Pertumbuhan Bakteri Staphylococcus aureus. Jurnal Farmasi \& Sains Indonesia. 2 (2). pp. 9-12. 